\title{
Denetçinin Mesleki Deneyiminin Denetim Kalitesine Etkisi
}

\author{
The Effect of the Auditor's Professional Experience on Audit Quality
}

\author{
Nurcan BULUT ${ }^{*}$
}

$\ddot{O} Z$

Küreselleşen dünyada muhasebe bilgi kullanıcıları karar alırken finansal tablolarda sunulan bilgilerin güvenilir ve kaliteli olmasını isterler. Güvenilir ve kaliteli bilgi ise bağımsız denetim ile sağlanmaktadır. Bă̆ımsız denetimin kalitesine etki eden gerek denetçi özelliklerinden, gerek denetim firmasından gerekse de çevreden kaynaklı birçok faktör söz konusudur. Bu doğrultuda çalışmada, denetçilerin mesleki deneyiminin denetim kalitesine etkisinin olup olmadı̆̆ının araştırılması amaçlanmıştır. Bu amaçla çalışmada öncelikle denetim kalitesi, mesleki deneyim ve denetim kalite çerçevesi ele alınmış, denetim kalite çerçevesinden hareketle bir ölçek oluşturulmuş ve test edilmiştir. Çalışmanın sonucunda hipotezler reddedilmiş ve denetçinin mesleki deneyimi ile denetim kalitesi arasında istatistiksel bir ilişki olmadı $\breve{l}$ görülmüşü̈r. Buradan yeni işe başlamış bir denetçiyle, mesleki deneyimi daha fazla olan bir denetçinin aynı kalitede denetim raporu hazırladı̆̆ sonucuna ulaşılmıştır.

\section{ANAHTAR KELIMELER}

Mesleki Deneyim, Denetim, Denetim Kalitesi

\begin{abstract}
In the globalizing world, accounting information users want the information presented in the financial statements to be reliable and of high quality while making decisions. Reliable and quality information is provided by independent auditing. There are many factors that affect the quality of the independent audit, originating from the characteristics of the auditor, the audit firm and the environment. In this regard, it is aimed to investigate whether the professional experience of the auditors has an effect on audit quality or not. For this purpose firstly, the audit quality, professional experience and audit quality framework were discussed in the study, a scale based on the audit quality framework was created and tested. As a result of the study, the hypotheses were rejected and it was observed that there was no statistical relationship between the auditor's professional experience and audit quality. From this point, there is no any difference in the way of preparinf of the audit report between the new starter and experienced auditor.
\end{abstract}

\section{KEYWORDS}

Professional Experience, Auditing, Audit Quality

\begin{tabular}{|c|c|c|}
\hline \multicolumn{2}{|r|}{$\begin{array}{c}\text { Makale Geliş Tarihi / Submission Date } \\
10.03 .2021\end{array}$} & $\begin{array}{c}\text { Makale Kabul Tarihi / Date of Acceptance } \\
\text { 07.04.2021 }\end{array}$ \\
\hline Attf & $\begin{array}{l}\text { Bulut, N. (2021). Denetçinin Mesleki } \\
\text { Meslek Yüksekokulu Dergisi, } 24 \text { (1), 1s }\end{array}$ & Kalitesine Etkisi. Selçuk Üniversitesi Sosyal Bilimler \\
\hline
\end{tabular}

\footnotetext{
* Dr. Öğr. Üyesi, Bitlis Eren Üniversitesi, İktisadi ve İdari Bilimler Fakültesi, İşletme Bölümü, Muhasebe ve Finansman ABD, nbulut@beu.edu.tr, ORCID: 0000-0002-8374-8350
} 


\section{GİRIŞ}

Bağımsız denetim, dış denetim ya da finansal tablo denetiminin amacı, yatırımcılara güven sağlamak, işletme yönetiminin sunduğu finansal tabloların gerçeği ne derece yansıttığını, önceden kabul edilmiş ölçütlere (genel kabul görmüş muhasebe ilkeleri) ne derece uyulduğunu, varsa hata, hile ve suiistimalleri ortaya çıkarmaktır. Ayrıca bağımsız denetimin bir diğer amacı da finansal tabloların kalitesine güven sağlamaktadır. Son yıllarda yaşanan şirket skandallarına baktığımızda denetimin bu amacına tam anlamıyla ulaşamadığını ve bağımsız denetime ve bağımsız denetçilere olan güvenin azaldığını söyleyebiliriz. Yaşanan bu denetim skandalları sonrasında denetimde kalite kavramı ortaya çıkmış, denetimi düzenleyici ve denetleyici kurum ve kuruluşlar tarafından denetim kalitesinin göstergeleri, denetim kalitesini etkileyen faktörler belirlenmiş ve denetim kalitesini arttırmak amacıyla çeşitli çalışmalar yapılmıştır. Denetim kalitesi soyut bir kavram olup çok boyutlu bir yapıya sahiptir, gerek denetim firmasından, denetlenen işletmeden, gerekse denetçinin kişilik özelliklerinden kaynaklı denetim kalitesine etki eden birçok faktör söz konusudur. Denetçinin mesleki deneyimi, denetçinin denetim mesleğindeki tecrübesini, denetim işine harcamış olduğu zamanı ifade etmektedir. Hangi meslek olursa olsun deneyim kazandıkça yapılan işte ustalaşılmakta, zaman tasarrufu sağlanmakta, işin incelikleri öğrenilip yapılan hatalar daha çabuk ortaya çıkarılabilmektedir. 26 Aralık 2012 tarihinde resmî gazetede yayınlanan bağımsız denetim yönetmeliğinde "Bağımsız Denetçinin Denetimde Yetkilendirilmesi" başlığı altında yetkilendirilecek meslek mensubunun sahip olacağı unvanlar ve unvana sahip olmak için gerekli olan deneyim, sorumlu denetçilerin yetkileri ve yer alacağı denetimler belirtilmiştir. Yayınlanmış olan bu yönetmelikle Kamu Gözetim Kurumu (KGK)'nun belirlemiş olduğu denetim meslek unvanları şöyledir (www.kgk.gov.tr, Erişim Tarihi: 01.02.2021):

Denetçi Yardımcısı: Denetim ekibine dâhil edilen fakat denetim ekibinde söz konusu denetim için yetkilendirilmeyen kişilerdir. En az 2 yıl bağımsız denetim firmasında görev alındığında denetçi yardımcısı olunur.

Denetçi: Yönetmeliğin 14. maddesinde yer alan şartları taşımış olmak ve yine yönetmeliğin 15 . maddesindeki en az 3 yıl süreyle, finansal tablo denetimini de içerecek şekilde mesleki faaliyetlere ilişkin denetçi yanında ya da denetim firmalarında uygulamalı eğitim alan kişilerdir.

Kıdemli Denetçi: Bağımsız denetim yetkilendirme belgesine sahip ve denetim mesleğinde en az 6 yıl çalışan meslek mensupları kıdemli denetçi unvanına sahip olurlar.

Baş Denetçi: Bağımsız denetim yetkilendirme belgesine sahip ve denetim mesleğinde en az 10 yıl çalışan meslek mensupları kıdemli denetçi unvanına sahip olurlar.

Sorumlu Denetçi: Denetim raporunu, denetim ekibi adına imzalama yetkisine sahip ve bağımsız denetim firması tarafından, bağımsız bir denetim faaliyetinin yürütülmesinden sorumlu olanlar sorumlu denetçi unvanına sahip olurlar.

$\mathrm{Bu}$ bağlamda bu çalışmanın amacı, denetçinin mesleki deneyiminin denetim kalitesine etkisinin olup olmadığını ortaya koymaktır. Bu amaçla öncelikle denetim kalitesi, mesleki deneyim ve Uluslararası Denetim ve Güvence Standartları Kurulu'nun hazırlamış olduğu denetim kalitesi çerçevesinden bahsedilmiş, daha sonra denetim kalite çerçevesinden hareketle bir ölçek oluşturulmuştur. Son olarak denetim kalitesi ölçeğin her boyutu ile denetçinin mesleki deneyimi arasındaki ilişkiye bakılmıştır.

\section{DENETIMDE KALITE KAVRAMI, GEREKLILIĞĞI VE ÖNEMI}

Bir kurumun rakiplerine karşı avantaj sağlaması, uzun vadede varlığını devam ettirmesi ve satışlarını artırmasında kalite çok önemlidir. Denetim kalitesi finansal raporlama sisteminin etkinliğinin sağlanmasında önemli bir paya sahiptir. Denetim kalitesi ve ölçümüyle ilgili çok geniş bir literatür olmasına rağmen genel kabul gören evrensel bir tanım ve ölçüm söz konusu değildir. Denetim kalitesinin tanımına denetim standartlarında da yer verilmemiştir. Fakat standartlar denetçilere denetimin nasıl yapılacağı konusunda rehberlik etmektedir. Standartlara ne derece uyulursa o derecede kaliteli bir denetim yapılmış olacaktır.

Kaliteli bağımsız denetim hizmeti, geçerli standartlara uygun olarak yürütülen, uygun bir mesleki şüphecilik düzeyine sahip titiz bir denetim sürecini içermektedir. Bunun yanı sıra kaliteli bir denetim için diğer gerekli olan unsurlar, sektör bilgisinin derinliği, denetim sürecinden kaynaklanan değerli iç görülerin ve gözlemlerin doğası ve kapsamını veya dünyanın birçok yerinden hizmetleri etkin bir şekilde koordine etme becerisidir (www.biac.org, Erişim Tarihi: 05.01.2021)

Denetim kalitesine ilişkin literatürde en kabul gören tanım DeAngelo'nun tanımıdır. DeAngelo yapmış olduğu tanımda denetim kalitesini finansal raporlama kalitesiyle ilişkilendirir. DeAngelo (1981) denetim kalitesini bir denetçinin önemli bir ihlali (yani yanıltıcı beyanı) vurgulayıp bulacağı ve daha sonra ilgili otoritelere rapor edeceği piyasa tarafindan geliştirilmiş bir varsayım şeklinde ifade etmektedir. $\mathrm{Bu}$ tanımın daha yakından analiz edilmesi, bu tanımın iki önemli özelliğini ortaya koyar: denetçinin finansal tablolardaki 
hata ve hileyi bulma yeteneği ve hata ve hileyi raporlayıp raporlamama konusundaki gerçek niyeti. Bu bağlamda, bu tanımın doğru bir gerçeği açıkça vurgulamadığını, ancak yalnızca denetçinin finansal tablolardaki önemli yanlışlığı tespit etme konumunda olacağına dair bir varsayıma 1şık tuttuğunu belirtmek çok önemlidir. Başka bir şekilde ifade edilecek olursa, ilk tanımın bu yönü, denetçinin profesyonel olarak donanımlı olacağını ve finansal tablolardaki gizli önemli yanlışlıkları ortaya çıkaracak kadar teknik açıdan sağlam ve yetkin olacağını varsayar. Ancak bu tanım, genellikle piyasada bulunan ve denetçinin rolü ve performansıyla ilgili bir varsayımın parçasıdır. Ek olarak, müşteriler denetçilerinin denetim kalitesinden ödün vermeden denetçilerinin beklentilerini profesyonel bir şekilde karşılamasını da bekler. (Al-Qatamin ve Salleh, 2020: 56).

Francis'in denetim kalitesi çerçevesi, denetim kalitesini etkileyen 6 boyuttan oluşmaktadır. Bunlar; denetim girdileri, denetim süreci, muhasebe firmaları, denetim sektörü ve denetim pazarları, kurumları ve denetim çıktılarının ekonomik sonuçlarıdır. Francis'e (2011) göre denetim, bir muhasebe firması bağlamında gerçekleşir. Muhasebe firmaları, müşterinin finansal tablolarıla birlikte denetim raporları düzenler. Denetçileri işe alır, eğitir ve ücretlendirir ve denetim yordamları geliştirirler (Tristchler, 2013:13).

Palmrose (1988), denetim kalitesini güvence seviyesi olarak tanımlamıştır ki bu güvence seviyesi finansal tabloların önemli eksiklikler ve yanlış beyan içermediği olasılığıdır. Daha yüksek güvence seviyeleri daha yüksek kaliteli hizmetleri ifade etmektedir. Bu tanımın önemli bir içerimi denetim başarısızlıklarının (önemli eksiklikler/yanıltıcı beyanlar içeren finansal tablolar) daha kaliteli hizmetlerle daha az olası hale gelmesidir (Palmrose, 1988: 56-57).

Denetim kalitesine ilişkin düzenleyici kurum ve kuruluşlar da tanımlamalar yapmışlardır. Amerika Birleşik Devleti Saymanlık Ofisi (GAO) yüksek denetim kalitesi tanımında standartlara uygunluk düzeyi ile finansal durumla ilgili güvence düzeyini birleştirir. GAO (2003)'ya göre denetlenmiş finansal tabloların ve ilgili açıklamaların genel kabul görmüş muhasebe ilkelerine uygun olarak sunulduğuna ilişkin makul güvence sağlanabilmesi için, denetimin genel kabul görmüş denetim standartlarına uyularak yapılması gerekmektedir. Yüksek kaliteli denetim finansal tabloların genel kabul görmüş muhasebe ilkelerine uygun hazırlandığının ve önemli ölçüde yanıltıcı beyan içermediğinin güvencesini verir. Bu tanım incelendiğinde tanımın sadece gerçek denetim kalitesini değil, aynı zamanda algılanan denetim kalitesini de içerdiği görülmektedir. Durumlar ve gerçekler ile ilgili makul bilgi sahibi olan üçüncü tarafların denetimin genel kabul görmüş denetim standartlarına uygun olarak yürütüldüğü, denetçinin genel kabul görmüş denetim standartlarına uygun olarak önemli yanlışlıkları şu şekilde tespit ettiği; (1) önemli yanlışlıkları önlemek için finansal tablolarda uygun düzeltmelerin, ilgili açılamaların ve diğer değişikliklerin yapılmasını sağlayarak, (2) uygun düzeltmeler ve diğer değişiklikler yapılmadığ 1 takdirde denetçinin finansal durumlara ilişkin görüşünü değiştirerek sonucuna vardığını varsayar (Tristchler, 2013:12-13).

Halka Açık Şirket Muhasebe Gözetim Kurulu (PCAOB)'nun alt grubu olan SAG denetim kalitesini, denetim firmasının çalışmalarının kalitesi şeklinde tanımlamıştır. Denetim firmasının çalışmalarının kalitesi, objektifliğe, zekâya, bütünlüğe, deneyime, motivasyona ve yetkinliğe bağlıdır. Aynı zamanda bir firmanın çalışmalarının kalitesinin işi yapan, denetleyen ve gözden geçiren personelin bütünlügüne bağlıdır (PCAOB, 2011).

Finansal Raporlama Konseyi (2008), denetçiler, denetim komiteleri, hazırlayıcılar, yatırımcılar ve diğer paydaşlar arasında denetim kalitesi konusunda etkili iletişimi desteklemek için bir çerçeve tasarlanmıştır. Çerçevenin, mevcut düzenlemeleri ve yönergeleri tamamlayıcı olması amaçlanmıştır ve denetim kalitesi şu temel faktörleri desteklemektedir: bir denetim firması içindeki kültür, denetim ortaklarının ve personelinin becerileri ve kişisel özellikleri, denetim sürecinin etkinliği, denetim raporlamasının güvenilirliği ve kullanışlılığı ve denetim kalitesini etkileyen denetçilerin kontrolü dışındaki faktörlerdir (www.frc.org.uk, Erişim Tarihi: 05.01.2021). 
Şekil 1. İngiltere Finansal Raporlama Konseyi: Denetim Kalite Çerçevesi

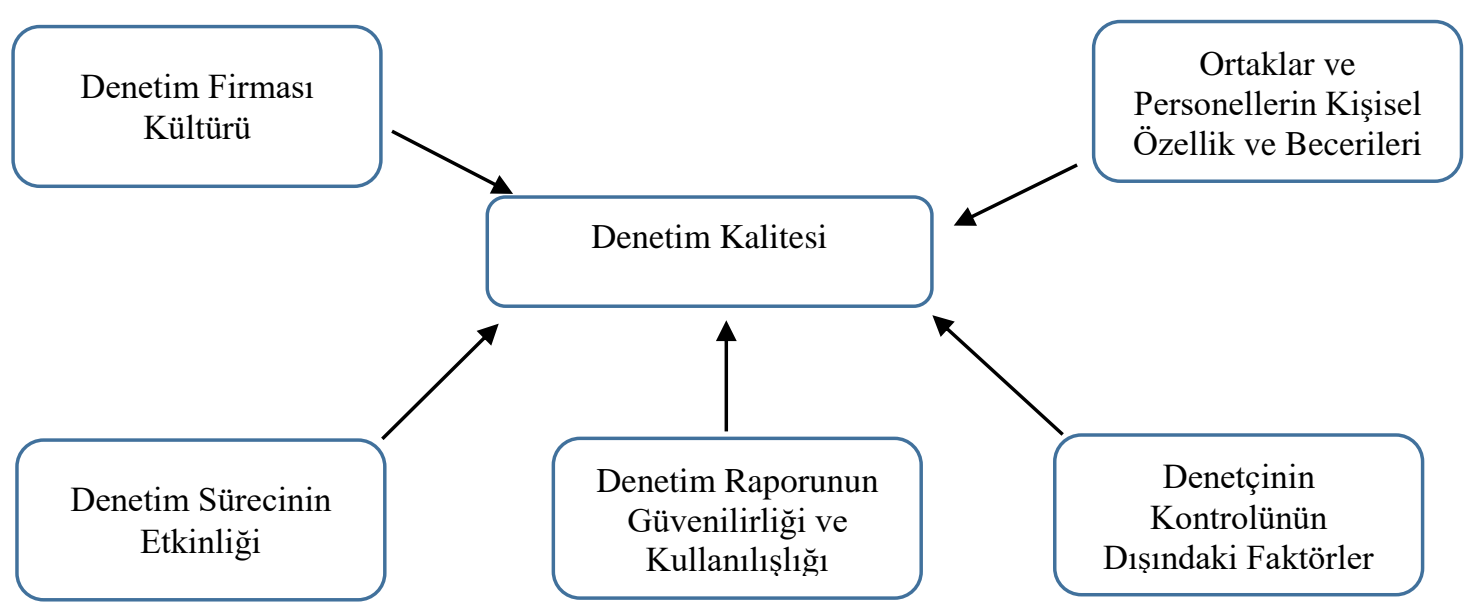

Kaynak: (Al-Qatamin ve Salleh, 2020: 59)

Yukarıda yapılan kalite tanımlarına ve ilgili hususlara dayalı olarak denetim kalitesinin çok boyutlu bir yapı olduğu söylenilebilir. Basitleştirilmiş bir ifadede, denetimin yarattığı değer ile üçüncü taraf kullanıcıların ve denetim müssterilerinin denetlenmesine yönelik beklentiler arasında bir teyit seviyesi olarak tanımlanabilir. Paydaşların ihtiyaçlarından kaynaklanan beklentiler şu durumlarda karşılanır veya üstesinden gelinir (Vaicekauskas ve Mackevicius, 2014:177):

- Denetçiler doğru ve güvenilir denetim raporu yayınlarsa,

- Denetçiler, denetim müşterileri için yararlı iç görüler ve tavsiyeler sunarak böylece sağlanan hizmetin katma değerini yaratırlarsa,

- Denetçiler hata ve hileden kaynaklanan önemli yanıltıcı beyan olasılığını azaltırlarsa,

- Denetim, tüm denetim aşamalarında mesleki standartlara, etik kurallara ve uygulanabilir yasalara uygun olarak yürütülürse,

- Denetim, yanıltıcı beyanları (beceri, deneyim) tespit edebilen ve bunları raporlayabilen (bağımsızlık), iyi itibarlarını önemseyen, uygun şekilde düzenlenmiş ve yönetilen denetim firmalarında çalışan yetkili denetçiler tarafından yapılırsa,

- Denetim müş̧terileri, sorumluluklarının farkına varırlar ve firma içinde kaliteli bir iç kontrol sistemi sağlarlarsa. 
Şekil 2. Denetim Kalitesini Anlamak ve Araştırmak İçin Bir Çerçeve

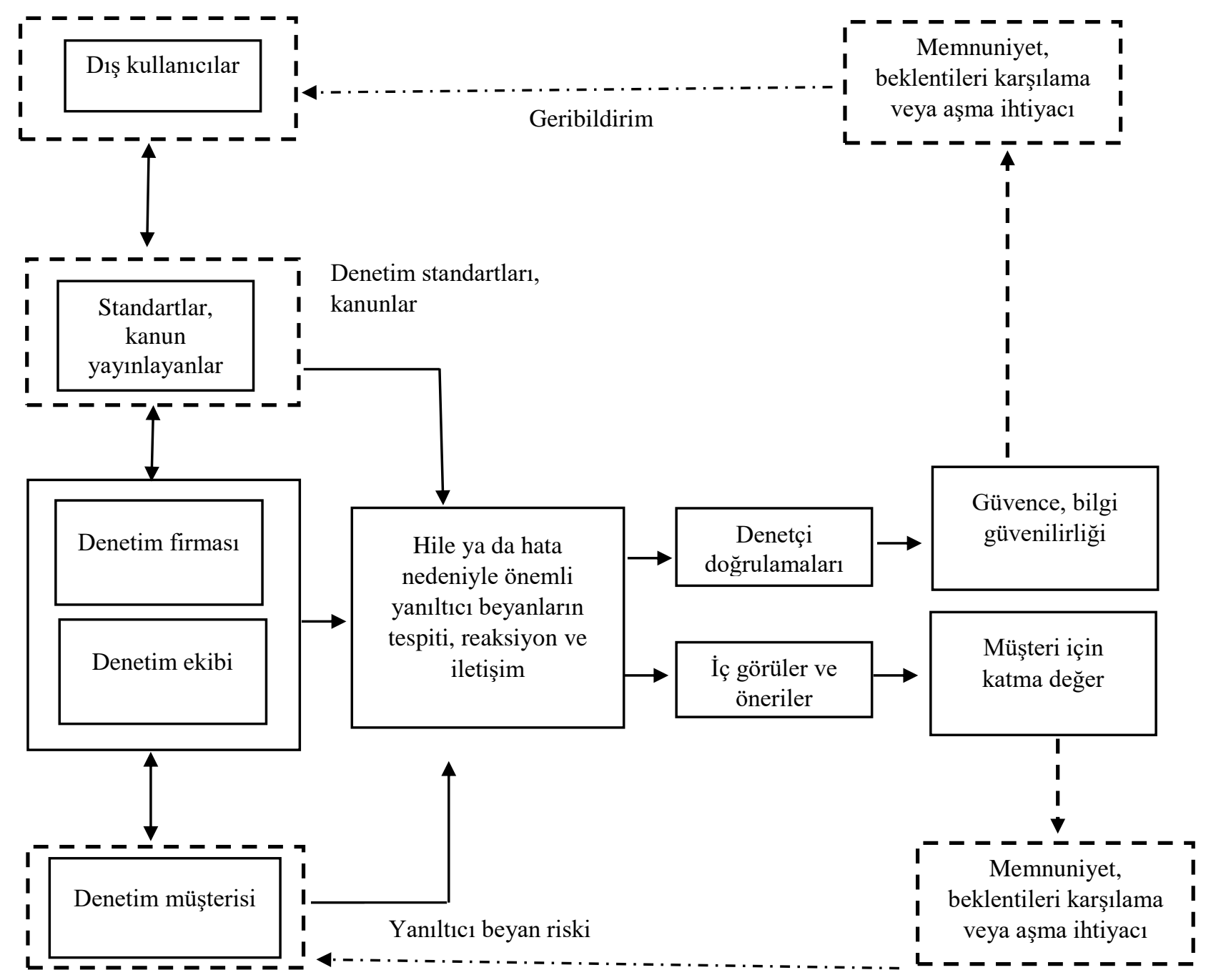

Geribildirim

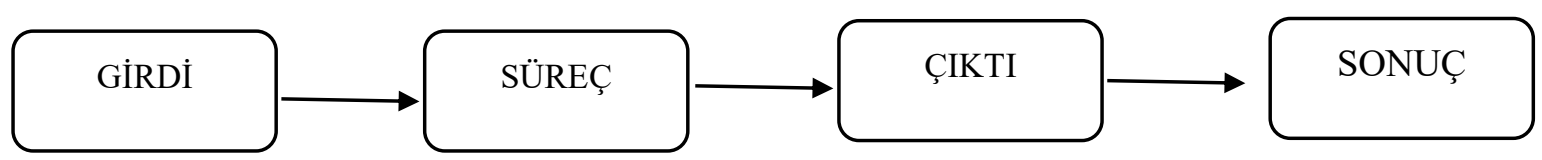

Denetçiler, denetim müşterilerinin finansal tablolarını belirlenen standartlar ve kanunlara göre denetlerler. Denetim işi, genellikle denetim firmaları adına denetçiler tarafından yerine getirilir. Denetim ekiplerinde çalışan denetçiler, belirli bir görevin kalitesini belirler, oysa uygun, iyi organize edilmiş ve yönetilen bir denetim işi, iyi değerlendirilmiş müşteri kabulü, etkili personel yönetimi, iş incelemesi yoluyla her bir görev üzerinde bir etkiye sahiptir. Bu, denetim firmalarının ve denetim ekiplerinin çeşitli özellikleri, üst düzey denetim firması yöneticileri tarafindan kontrol edilen iç denetim kalite faktörleri olarak görülebilir (Vaicekauskas ve Mackevicius, 2014:178).

Denetim kalitesi, güçlü bir sermaye piyasasının zorunlu araçlarından biridir, bu sebeple bir bağımsız denetim finansal tabloların değerini artırabilir ve şeffaf finansal raporlama ile kurumsal yönetim faaliyetlerini doğrudan teşvik edebilir. Denetim kalitesi aynı zamanda, denetlenen işletmelerin performansının iyileştirilmesine katkı sağlar. Büyük işletmeler, denetim hatalarını ve kusurlarını azaltmak için yüksek miktarda fon ayırırlar, bu da iyi performans sağlanmasına neden olur. İşletmelerin finansal raporlamalarının iyileştirilmiş kalitesi, etkili bir denetim kalitesi ile ilişkilidir (Sattar vd., 2020: 5).

Denetim kalitesi denetim raporlarının veya finansal tabloların güvenilirliğini artırmaya katkıda bulunduğu için, bu yöndeki çabaları ikiye katlama ihtiyacı giderek bir zorunluluk olarak kabul edilmektedir. Finansal tabloların güvenilirliğini arttırmaya yönelik katkılar, esas olarak bir firmanın imajı ve itibarını olumlu etkiler. Denetlenmiş finansal tablolara daha fazla güvence ve güven ile kamu çıkarları da korunur. Bu durumun daha 
sürdürülebilir bir şekilde başarının sağlanmasına önemli katkı sağladığı ifade edilmektedir. Yapılan çalı̧̧malarda firmanın itibarı ile ilgili olarak, bir firmanın sürekli olarak en yüksek kalitede denetimler yaparak itibarını oluşturduktan sonra, firmaya güvenin artması sayesinde firmanın yatırımları çekerek kazanmaya devam edeceği ifade edilir. Bu türden bir kredi değerliliğinin doğrudan yararı, karar vericilerin ve yatırımcıların denetçinin bulgularına, sonuçlarına veya tavsiyelerine daha fazla değer vermeleri ve bunları uygulamaya daha yatkın olmalarıdır. Bu nedenle, denetim kalitesinin en yüksek uluslararası standartlarda sağlanması ihtiyacı, yerli ve yabancı doğrudan yatırım akışlarını canlandırabilir (Mushiirah vd, 2018: 2775).

Denetim kalitesi, denetlenen işletmenin performansının iyileştirilmesi için önemlidir, çünkü denetim kalitesi paydaş güvenini oluşturur ve bu da daha yüksek karlılığa katkı sağlar. Ekonomik kurumlar, piyasa güçlerinin, işletmeleri uluslararası muhasebe kurallarını ve düzenlemelerini benimsemeye zorlayan denetim kalitesi üzerinde büyük etkileri olduğunu savunmaktadır. Ayrıca, işletmeler için aracılık maliyetini düşürmek her zaman en önemli önceliktir ve rekabet, aracılık maliyetini en aza indirmede önemli bir rol oynar (Sattar vd., 2020: 6).

Özet olarak, kaliteli bir denetim hizmeti sunabilmek için bağımsız denetçiler, finansal raporların önemli yanlışl1k içermediğine dair makul güvence elde etmeli, muhasebe tahminlerine ve yöntemlerine yeterli şüphecilik uygulamalı ve tespit edilen eksiklikleri gidermeli, böylece yatırımcılar ve diğer finansal rapor kullanıcıları finansal raporların içerdikleri bilgilerin kalitesine güvenebileceklerdir (www.asic.gov.au, Erişim Tarihi, 06.01.2021).

\section{DENETIMDE MESLEKI DENEYIM}

Mesleki deneyim, bir öğrenme süreci şeklinde tanımlanır ve çalışma alanında örgün ve yaygın eğitim ile daha iyi kişisel yeteneklerin gelişimini ve daha yüksek beceriye sahip biri olma sürecini geliştirir. Mesleki deneyim, denetçinin denetimi yapma becerisini geliştirir. Denetçinin mesleki deneyimi, denetçi tarafından gerçekleştirilen görevlerin süresini ve sayısını etkiler. Bunların her ikisi de denetçinin denetimi yaparken uzmanlığını artırır. Denetçi, denetim vakalarını ne kadar sık ele alırsa özellikle de denetim yargısı oluştururken denetimlerin kalitesini artıracaktır. Davranışsal karar verme teorisinde, karar verirken (denetçi yargısını oluştururken) denetçinin birçok şeyden etkileneceğini açıklar. Bu durumda denetçinin mesleki deneyimi, denetçinin bir denetim görüşü sağlama kararında çok etkilidir. (Zahmatkesh ve Rezazadeh, 2017: 79, Prasanti vd., 2019: 225).

Daha fazla deneyimli denetçiler, daha az deneyime sahip denetçilerden daha fazla bilgi ve bellek yapısına sahip olacaklardır. Öyle ki denetçilerin tecrübesi ve profesyonelliği arttıkça, belirlenen kararlar daha "hesap verebilir" olacaktır. Yüksek kaliteye sahip denetçilerin, denetim raporunun kullanıcısı için yüksek düzeyde güvenilirlik sağlayabileceği kabul edilmektedir (Noverini ve diğ, 2020: 273).

\section{DENETIM KALITESI İÇIN ÇERÇEVE}

AASB (Uluslararası Denetim ve Güvence Standartları Kurulu)'nin denetim kalitesine ilişkin hazırlamış olduğu çerçeve İngiltere Finansal Raporlama Konseyi'nin yaptığı gibi aynı unsurları ve özellikleri kapsar. Ancak, denetim kalitesine ilişkin 1AASB'nin çerçevesi daha kapsamlı ve ayrıntılıdır (Tristchler, 2013: 24).

IAASB'nin faaliyetlerini denetleyen Kamu Çıkarı Gözetim Kurulu (PIOB)'nun ve kamu yararına girdi sağlayan IAASB Danışma Tavsiye Grubunu içeren ortak bir standart belirleme süreci altında tüm muhasebe meslek mensupları tarafından kullanılmak üzere denetim ve güvence standartları ve rehberliği geliştirilmiştir. IAASB' nin amac1, yüksek kaliteli denetim, güvence ve diğer ilgili standartları belirleyerek ve uluslararası ve ulusal denetimin yakınsamasını kolaylaştırarak kamu yararına hizmet etmektir. Güvence standartları, böylece dünya çapında uygulamanın kalitesini ve tutarlılığını arttırır ve küresel denetim ve güvence mesleğine yönelik halkın güvenini güçlendirir. IAASB' nin denetim kalitesi çerçevesinin amacı, denetim kalitesinin temel unsurları hakkında farkındalık yaratmak, kilit paydaşları denetim kalitesini iyileştirmenin yollarını keşfetmeye teşvik etmek, konuyla ilgili kilit paydaşlar arasında daha fazla iletişimi kolaylaştırmaktır. IAASB, çerçevenin denetim kalitesinde sürekli iyileştirme sağlamak için tartışma ve olumlu eylemler oluşturmasını beklemektedir (IAASB, 2014:1).

Finansal tabloların denetiminin amacı, denetçinin, finansal tabloların yanıltıcı beyan içerip içermediğine ilişkin yeterli ve uygun denetim kanıtı elde etmiş olmasına dayanarak finansal tablolar hakkında bir görüş oluşturması ve denetçinin denetim kanıtlarını değerleyerek yargıya varmasıdır. Aşağıdaki özelliklere sahip bir denetim ekibi tarafından kaliteli denetim gerçekleştirilmiş olması yüksek ihtimaldir (IAASB, 2014: 4):

- Uygun değerler, etik ve tutumlar sergileyen,

- Yeterince bilgili, yetenekli ve tecrübeli ve denetim işini gerçekleştirmek için yeterli zamanı ayıran, 
- Yasalara uygun titiz bir denetim süreci ve kalite kontrol prosedürleri uygulayan, düzenleme ve uygulanabilir standartlar,

- Faydalı ve zamanında raporlar sağlayan,

- İlgili paydaşlarla uygun şekilde etkileşim kuran.

Çerçeve, denetim kalitesinin temel unsurlarına ilişkin farkındalı̆̆ arttırmayı ve böylece denetçileri, denetim firmalarını ve diğer paydaşları kendi ortamlarında denetim kalitesini arttırmak için yapabilecekleri daha fazla şey olup olmadığı konusunda kendilerine meydan okumaya teşvik etmeyi amaçlamaktadır. Çerçeve, büyüklükleri, nitelikleri ve karmaşıklıkları ne olursa olsun tüm kuruluşların denetimleri için geçerlidir. Aynı zamanda, bir ağın veya birliğin parçası olan denetim firmaları da dâhil olmak üzere, büyüklükten bağımsız olarak tüm denetim firmaları için de geçerlidir (IAASB, 2014: 4).

Kalite için geliştirilen çerçeve girdi ile ilgili faktörler, süreç ile ilgili faktörler, çıtı ile ilgili faktörler, bu faktörler arasındaki etkileşim ve çevresel faktörler olmak üzere beş kısımdan oluşmaktadır. Çerçeve finansal tabloların denetiminde denetimin kalitesine denetim işi, denetim firması ve ulusal düzeyde etki eden girdi, süreç ve çıktı faktörlerini ve çeşitli çevre faktörleri ile paydaşlar arasındaki uygun etkileşimin önemini ortaya koymaktadır. Denetim sürecinin girdi faktörleri, denetim firmasında hâkim olan kültürün etkisinde kalan denetçilerin değerleri, etikleri ve tutumları ve denetçilerin bilgi, beceri ve deneyimleri ile denetimi gerçekleştirmek için kendilerine tahsis edilen zamandır. Süreç faktörleri, denetim sürecinin ve kalite kontrol prosedürlerinin titizliği denetim kalitesinde etkili olmaktadır. Çıktı faktörleri, genellikle denetlenen kuruluşun dışındakiler tarafından görülemeyen denetim sürecinden kaynaklanan çıktıları içerir. Finansal raporlamanın niteliğini ve kalitesini ve doğrudan veya dolaylı olarak denetim kalitesini etkileme potansiyeline sahip olan yasalar ve yönetmelikler ve kurumsal yönetişim gibi bir dizi çevresel veya bağlamsal faktörler vardır. Denetçiler, uygun olduğu durumlarda, yeterli ve uygun denetim kanıtının en iyi şekilde nasıl elde edileceğini belirlerken bu faktörlere cevap verir.

\section{ARAŞTIRMANIN METODOLOJISI}

\subsection{Araştırmanın Konusu ve Amacı}

Bağımsız denetimin amacına ulaşabilmesi ve kaliteli denetimin yapılabilmesi için denetim işinin alınmasından denetim raporunun hazırlanmasına kadar denetimin tüm aşamalarında denetçi uygun seviyede mesleki dikkat ve özen göstermeli, şüpheci bir yaklaşımla hareket etmeli ve bağımsız davranmalıdır. Denetçinin sahip olduğu mesleki deneyim de denetçinin işi daha hızlı tamamlamasını, hataları daha hızlı ortaya çıkarmasını sağlayacaktır. Çalışmanın amacı denetçinin mesleki deneyiminin denetim kalitesi üzerinde etkisinin olup olmadığını ortaya koymaktır.

\subsection{Araştırmanın Kapsamı}

Araştırmanın kapsamına fiilen bağımsız denetim yapan denetçiler gönüllülük esasına göre çalışmaya dahil edilmiştir ve çalışma için etik kurul onayı alınmıştır. Çalışmanın evreni fiilen bağımsız denetim hizmeti sunan denetçilerdir. Örnekleme yöntemi olarak ise kartopu örneklemesi kullanılmıştır. Ülkemizde bağımsız denetim kuruluşu ve bağımsız denetçi yetkilendirilmesi Kamu Gözetim Kurumu tarafından yapılmaktadır. 31.12. 2019 tarihi itibariyle yetkilendirilen denetçi sayıs1 (SMMM, YMM) 18.621, tescil edilen 16.650, tescil talebinde bulunmayanlar 1.971'dir. Bağımsız denetim yetkilendirmesi alan denetçilerin hepsi fiilen denetim faaliyetinde bulunmamaktadırlar. Denetçinin mesleki deneyiminin denetim kalitesine etkisini tespit etmek amaciyla hazırlanan anket formu fiilen bağımsız denetim yapan denetçilere uygulanmıştır. Araştırmanın evrenini Kamu Gözetim Kurumu'nda yetkilendirme alan denetçiler oluşturmaktadır. Formlar denetçilerin mail adreslerine gönderilerek ve yüz yüze cevaplanmıştır. Toplam 200 denetçi formları cevaplayıp geri dönüş sağlamıştır.

\subsection{Araştırmanın Yöntemi}

Araştırma için denetçilerden veriler anket yöntemiyle elde edilmiştir. Çalışmada kullanılan anket formu iki kısımdan oluşmaktadır. Formun ilk bölümü denetçilerin sosyo-demografik özelliklerini içermektedir. Denetçilerin bu özellikleri cinsiyet, yaş, mesleki deneyim ve denetim mesleğindeki unvanı gibi bilgilerden oluşmaktadır. İkinci kısımda ise IAASB'nin denetim kalite çerçevesi ve Sulaiman'ın (2011) çalışmasından hareketle 38 maddelik (sırasıyla 9 soru girdi, 14 soru süreç, 10 soru çıkt1 ve son 5 soru çevresel faktörler) bir ölçek geliştirilmiştir. Anket formuna katılımcıların cevap vermesi amaciyla 5'li Likert (1.Kesinlikle

Katılmıyorum, 2. Katılmıyorum, 3. Kararsızım, 4.Katılıyorum, 5. Kesinlikle Katıllyorum) ölçeği kullanılmıştır. Verilerin analizi için SPSS paket programı kullanılmıştır. 
Denetim kalitesine ilişkin 38 maddeden oluşan ölçeğe ilk olarak betimleyici istatistikler, madde istatistikleri uygulanmıştır. Ayrıca yapı geçerliliğini test etmek için de faktör analizi uygulanmıştır. Faktör yükü 0,50'nin üzerinde olan maddeler seçilmiştir, faktör yükü, 0,50'nin altında olan ve binişik faktör yüküne sahip olan maddeler analizden çıkarılmıştır.

\subsection{Güvenilirlik Analizi, Kaiser Mayer Olkin ve Barlett'in Küresellik Testi}

Analiz aşamasında ilk olarak faktör gruplarının güvenilir olup olmadığını test etmek için Cronbach Alpha $(\alpha)$ katsayısı yöntemi kullanılmıştır. Cronbach Alpha $(\alpha)$ değeri 0,926'dır. Bu değere göre ölçeğin güvenilirliği yüksek seviyededir.

Örneklem büyüklüğünün yeterli olup olmadığını test etmek için Kaiser Mayer Olkin (KMO) değerine bakılmıştır. Bu değerin 1'e yakın olması ve 0.5 'in üzerinde olması beklenir. Değer 1'e yaklaştıkça örneklem de faktör analizine o derece uygun olacaktır (Hair vd, 2006). KMO değeri 0,889'dur. KMO değerine göre faktör analizi için örneklem büyüklüğünün yeterli olduğu görülmüsstür. Değişkenler arasındaki korelasyonun yeterli olup olmadığını tespit etmek için Barlett'in Küresellik Test (Barlett's Test of Sphericity) değerine bakılmıştır. Bu testin anlamlılık düzeyi $\mathrm{p}$ değeri $<0,05$ ise veriler faktör analizine uygundur. Ölçek için $\mathrm{p}$ değeri $<0,001$ 'dir. Ölçeğin test sonucu anlamlılık düzeyi \%5'ten küçük olduğundan korelasyon matrisi birim matrisi değildir.

\subsection{Araştırmanın Hipotezleri}

Araştırmanın amacına yönelik olarak hazırlanan hipotezler;

$\mathrm{H}_{1}$ : Denetçinin mesleki deneyimi ile girdi faktörleri arasında anlamlı bir ilişki vardır.

$\mathrm{H}_{2}$ : Denetçinin mesleki deneyimi ile süreç faktörleri arasında anlamlı bir ilişki vardır.

$\mathrm{H}_{3}$ : Denetçinin mesleki deneyimi ile çıktı faktörleri arasında anlamlı bir ilişki vardır.

$\mathrm{H}_{4}$ : Denetçinin mesleki deneyimi ile çevresel faktörler arasında anlamlı bir ilişki vardır.

\section{ARAŞTIRMANIN BULGULARI}

Katılımcıların sosyo-demografik özellikleri Tablo 1'de verilmiştir.

Tablo 1. Katılımcıların Sosyo-Demografik Özellikleri

\begin{tabular}{|c|c|c|c|}
\hline Özellikler & Gruplar & $\mathbf{N}$ & Yüzde (\%) \\
\hline \multirow{4}{*}{ Cinsiyet } & Kadın & 39 & 19,5 \\
\hline & Erkek & 156 & 78 \\
\hline & Cevaplamayan & 5 & 2,5 \\
\hline & Toplam & 200 & 100 \\
\hline \multirow{8}{*}{ Yaş } & $20-25$ & 15 & 7,5 \\
\hline & $26-35$ & 59 & 29,5 \\
\hline & $36-45$ & 60 & 30 \\
\hline & $46-55$ & 27 & 13,5 \\
\hline & $56-65$ & 14 & 7 \\
\hline & 66 üstü & 13 & 6,5 \\
\hline & Cevaplamayan & 12 & 6 \\
\hline & Toplam & 200 & 100 \\
\hline \multirow{8}{*}{ Deneyim } & $1-5$ & 60 & 30 \\
\hline & $6-10$ & 28 & 14 \\
\hline & $11-15$ & 38 & 19 \\
\hline & $16-20$ & 24 & 12 \\
\hline & $21-25$ & 13 & 6,5 \\
\hline & 26 üstü & 25 & 12,5 \\
\hline & Cevaplamayan & 12 & 6 \\
\hline & Toplam & 200 & 100 \\
\hline \multirow{7}{*}{ Unvan } & Sorumlu denetçi & 56 & 28 \\
\hline & Baş denetçi & 27 & 13,5 \\
\hline & Kıdemli denetçi & 28 & 14 \\
\hline & Denetçi & 42 & 21 \\
\hline & Denetçi yardımcısı & 33 & 16,5 \\
\hline & Cevaplamayan & 14 & 7 \\
\hline & Toplam & 200 & 100 \\
\hline
\end{tabular}

Selçuk Üniversitesi Sosyal Bilimler Meslek Yüksekokulu Dergisi, Yıl: 2021 Cilt: 24 Sayı:1 
Tabloda da görüldüğü gibi katılımcıların büyük bir çoğunluğu \%78'i erkek, \%19,5'i de kadındır. Katılımcıların \%30'u 36-45 yaş arasında, \%7,5'i ise 20-25 yaş arasındadır. Katılımcıların \%30'u 1-5 yıl arası \%6,5'i ise 21-25 yaş arası deneyime sahiptir. Katılımcıların \%28'i sorumlu denetçi, \%13,5'i baş denetçi unvanına sahiptir.

Denetim kalitesi ölçeğinin faktörlerinin ortalama ve standart sapma değerleri Tablo 2'de verilmiştir.

Tablo 2. Faktörlerin Ortalama ve Standart Sapma Değerleri

\begin{tabular}{|l|l|r|r|}
\hline Faktörler & Maddeler & Ortalama & Standart Sapma \\
\hline Girdi & M1 & 4,84 & 0,403 \\
& M2 & 4,84 & 0,423 \\
& M3 & 4,81 & 0,440 \\
& M4 & 4,56 & 0,679 \\
\hline Sürec & M5 & 4,71 & 0,520 \\
& M6 & 4,62 & 0,564 \\
& M7 & 4,68 & 0,539 \\
& M8 & 4,78 & 0,535 \\
& M9 & 4,68 & 0,546 \\
\hline Çıktı & M10 & 4,05 & 0,994 \\
& M11 & 3,39 & 1,325 \\
& M12 & 3,07 & 1,394 \\
& M13 & 4,32 & 0,868 \\
& M14 & 4,40 & 0,772 \\
& M15 & 4,34 & 0,868 \\
\hline Çevresel Faktörler & M16 & 4,42 & 0,888 \\
& M17 & 4,49 & 0,753 \\
& M18 & 4,52 & 0,837 \\
& M19 & 4,24 & 0,884 \\
& M20 & 4,45 & 0,760 \\
\hline
\end{tabular}

Tabloda da görüldüğü gibi her bir ifadenin ortalaması 3’ün üzerindedir. Denetçiler denetim kalitesine ilişkin yöneltilen ifadelere çoğunlukla katılmışlardır.

Keşfedici faktör analizi sonucu faktör yükü 0,50'nin altında olan ve binişik faktör yüküne sahip olan maddeler analizden çıkartılmış olup, kalite ölçeği için 20 maddeden oluşan dört boyutlu faktöriyel bir yapı oluşmuştur. Keşfedici faktör analizi sonucu kalite ölçeğindeki 4 faktör toplam varyansın \%61,956'sını açıklamaktadır. Keşfedici faktör analizi sonucu, kalite ölçeği için elde edilen faktörlerin faktör yükleri, açıklanan varyans yüzdeleri ve Cronbach Alfa $(\alpha)$ değerleri aşağıdaki tabloda verilmiştir.

Tablo 3. Denetim Kalitesi Ölçeği Faktör Analizi

\begin{tabular}{|c|c|c|c|c|}
\hline Faktör & Madde & $\begin{array}{l}\text { Faktör } \\
\text { Yükü }\end{array}$ & $\begin{array}{l}\text { Açılanan } \\
\text { Varyans (\%) }\end{array}$ & $\begin{array}{l}\text { Cronbach } \\
\text { Alfa }(\alpha)\end{array}$ \\
\hline \multirow[t]{4}{*}{ Girdi } & $\begin{array}{l}\text { Denetim işini yapan denetçi, işin gereği olan } \\
\text { bilgi, beceri ve deneyime sahip olmalıdır. }\end{array}$ & 0,854 & \multirow[t]{4}{*}{19,437} & \multirow[t]{4}{*}{0,796} \\
\hline & $\begin{array}{l}\text { Denetim işini yapan denetçi, işin gereği olan etik } \\
\text { ve değerlere göre hareket etmelidir. }\end{array}$ & 0,829 & & \\
\hline & $\begin{array}{l}\text { Denetim işini yapan denetçi, işin gereği olan } \\
\text { davranışları (mesleki özen ve dikkat) } \\
\text { göstermelidir. }\end{array}$ & 0,856 & & \\
\hline & $\begin{array}{l}\text { Denetim işini yapan denetçi, işin gereği olan } \\
\text { uygun davranışları gösterebilmek için eğitim } \\
\text { almalıdır. }\end{array}$ & 0,523 & & \\
\hline \multirow[t]{3}{*}{ Süreç } & $\begin{array}{l}\text { Denetimde önemlilik seviyeleri doğru } \\
\text { belirlenmelidir. }\end{array}$ & 0,510 & \multirow[t]{3}{*}{15,507} & \multirow[t]{3}{*}{0,744} \\
\hline & $\begin{array}{l}\text { Denetimde örneklem büyüklüğü doğru } \\
\text { belirlenmelidir. }\end{array}$ & 0,581 & & \\
\hline & $\begin{array}{l}\text { Denetçi, alternatif denetim yordamlarını dışsal } \\
\text { doğrulama taleplerine verilen cevapların }\end{array}$ & 0,636 & & \\
\hline
\end{tabular}




\begin{tabular}{|c|c|c|c|c|}
\hline & \multicolumn{2}{|l|}{$\begin{array}{l}\text { doğruluğundan şüphe etmesi durumunda } \\
\text { uygulamalıdır. }\end{array}$} & & \\
\hline & $\begin{array}{l}\text { Denetçi, denetim görüşüne dayanak oluşturacak } \\
\text { yeterli ve uygun denetim kanıtlarını elde } \\
\text { etmelidir. }\end{array}$ & 0,681 & & \\
\hline & $\begin{array}{l}\text { Denetçi, tamamlanan denetim dosyalarında } \\
\text { yeterli ölçüde belgelendirme yapmalıdır. }\end{array}$ & 0,632 & & \\
\hline \multirow[t]{6}{*}{ Çıktı } & $\begin{array}{l}\text { Müşsteri işletme ile çalışılan yıl sayısı denetim } \\
\text { kalitesinin sağlanmasında önemlidir. }\end{array}$ & 0,673 & \multirow[t]{6}{*}{14,091} & \multirow[t]{6}{*}{0,785} \\
\hline & $\begin{array}{l}\text { Denetim işi, müşteri tarafindan } \\
\text { değerlendirilmelidir. }\end{array}$ & 0,801 & & \\
\hline & $\begin{array}{l}\text { Denetim işi, müşterilerin beklentilerini } \\
\text { karşılamalıdır. }\end{array}$ & 0,806 & & \\
\hline & $\begin{array}{l}\text { Denetçi, müşteri işletmenin yönetimi işle etkin } \\
\text { bir iletişim sağlamalıdır. }\end{array}$ & 0,746 & & \\
\hline & $\begin{array}{l}\text { Denetçi, denetim komitesi ile etkin bir iletişim } \\
\text { sağlamalıdır. }\end{array}$ & 0,687 & & \\
\hline & $\begin{array}{l}\text { Denetçi, yönetişimden sorumlu olanlar ile etkin } \\
\text { bir iletişim sağlamalıdır. }\end{array}$ & 0,738 & & \\
\hline \multirow[t]{6}{*}{$\begin{array}{l}\text { Çevresel } \\
\text { Faktörler }\end{array}$} & $\begin{array}{l}\text { Yasa ve düzenlemeler denetim kalitesi için } \\
\text { önemlidir. }\end{array}$ & 0,754 & \multirow[t]{5}{*}{12,920} & \multirow[t]{5}{*}{0,842} \\
\hline & $\begin{array}{l}\text { Yetenekli kişilerin mesleğe çekilmesi denetim } \\
\text { kalitesi için önemlidir. }\end{array}$ & 0,722 & & \\
\hline & $\begin{array}{l}\text { Denetim firmasının kurumsal yönetim } \\
\text { anlayışının güçlü olması denetim kalitesi için } \\
\text { önemlidir. }\end{array}$ & 0,796 & & \\
\hline & $\begin{array}{l}\text { Finansal raporlama zaman çizelgesi denetim } \\
\text { kalitesi için önemlidir. }\end{array}$ & 0,801 & & \\
\hline & $\begin{array}{l}\text { Denetimde bilgi sistemlerinin kullanımı denetim } \\
\text { kalitesi için önemlidir. }\end{array}$ & 0,819 & & \\
\hline & Toplam & & 61,956 & \\
\hline
\end{tabular}

Denetçilerin mesleki deneyimi ile denetim kalitesi arasındaki ilişkiyi ortaya koymak için regresyon analizi yapılmıştır. Kalite ölçeğinin her bir boyutu için maddelerin ortalaması alınmış; girdi, süreç, çıktı ve çevresel faktörler için skorlar oluşturulmuştur. Mesleki deneyim bağımsız değişken, kalite ölçeğinin boyutları da bağımlı değişkendir. Bu değişkenlere regresyon analizi yapılmıştır.

Tablo 4. Denetçinin Mesleki Deneyiminin Girdi Faktörlerini Yordamasına İlişkin Regresyon Analizi

\begin{tabular}{|l|l|l|l|l|l|l|l|l|l|l|}
\hline Bağımsız Değişken & $\begin{array}{l}\text { Bağımlı } \\
\text { Değişken }\end{array}$ & $\mathbf{B}$ & $\begin{array}{l}\text { Std. } \\
\text { Hata }\end{array}$ & $(\boldsymbol{\beta})$ & $\mathbf{t}$ & $\mathbf{P}$ & $\mathbf{R}$ & $\mathbf{R}^{\mathbf{2}}$ & $\mathbf{F}$ & $\mathbf{P}$ \\
\hline Mesleki Deneyim & Girdi Faktörleri & 18,887 &, 084 &, 060 & 91,007 &, 00 &, 060 &, 004 &, 642 &, 424 \\
\hline
\end{tabular}

Anlamlılık düzeyi (significance) $\mathrm{p}>.05$ olduğu için kurulan regresyon modeli anlamsızdır. İlişkinin yordanmasına yönelik yapılan regresyon analiz sonuçlarına göre denetçilerin mesleki deneyimlerinin girdi faktörleri üzerinde etkisi olmadığı görülmektedir. Dolayısıyla $\mathrm{H}_{1}$ hipotezi reddedilmektedir.

Tablo 5. Denetçinin Mesleki Deneyiminin Süreç Faktörlerini Yordamasına İlişkin Regresyon Analizi

\begin{tabular}{|l|l|l|l|l|l|l|l|l|l|l|}
\hline Bağımsız Değişken & $\begin{array}{l}\text { Bağımlı } \\
\text { Değişken }\end{array}$ & $\mathbf{B}$ & $\begin{array}{l}\text { Std. } \\
\text { Hata }\end{array}$ & $(\boldsymbol{\beta})$ & $\mathbf{t}$ & $\mathbf{P}$ & $\mathbf{R}$ & $\mathbf{R}^{\mathbf{2}}$ & $\mathbf{F}$ & $\mathbf{P}$ \\
\hline Mesleki Deneyim & Süreç Faktörleri & 37,596 &, 430 &, 069 & 87,438 &, 00 &, 069 &, 005 &, 820 &, 366 \\
\hline
\end{tabular}

Anlamlılık düzeyi (significance) $\mathrm{p}>.05$ olduğu için kurulan regresyon modeli anlamsızdır. İlişkinin yordanmasına yönelik yapılan regresyon analiz sonuçlarına göre denetçilerin mesleki deneyimlerinin süreç faktörleri üzerinde etkisi olmadığı görülmektedir. Dolayısıyla $\mathrm{H}_{2}$ hipotezi reddedilmektedir. 
Tablo 6. Denetçinin Mesleki Deneyiminin Çıktı Faktörlerini Yordamasına İlişkin Regresyon Analizi

\begin{tabular}{|l|l|l|l|l|l|l|l|l|l|l|}
\hline Bağımsız Değişken & $\begin{array}{l}\text { Bağımıı } \\
\text { Değıişken }\end{array}$ & $\mathbf{B}$ & $\begin{array}{l}\text { Std. } \\
\text { Hata }\end{array}$ & $(\boldsymbol{\beta})$ & $\mathbf{t}$ & $\mathbf{P}$ & $\mathbf{R}$ & $\mathbf{R}^{\mathbf{2}}$ & $\mathbf{F}$ & $\mathbf{P}$ \\
\hline Mesleki Deneyim & Çıktı Faktörleri & 24,660 &, 589 &, 176 & 41,843 &, 00 &, 176 &, 031 & 5,383 &, 022 \\
\hline
\end{tabular}

Anlamlılık düzeyi (significance) $\mathrm{p}<.05$ olduğu için kurulan regresyon modeli anlamlıdır. İlişkinin yordanmasına yönelik yapılan regresyon analiz sonuçlarına göre denetçilerin mesleki deneyimlerinin çıktı faktörleri üzerinde pozitif yönde ve zayıf düzeyde anlamlı bir etkisinin olduğu görülmektedir. Modelin açıklama gücü olarak ifade edilen $\mathrm{R}^{2}$ değeri ,031 olarak hesaplanmıştır. Bu değer çıktı faktörleri değişkeninin \%0,31'inin modeldeki bağımsız değişken, yani denetçinin mesleki deneyimi tarafından açıklandığını gösterir. Buna göre denetçinin mesleki deneyimi $\mathrm{p}<.05$ olduğu için denetim kalitesi üzerinde anlamlı bir etkiye sahiptir. Dolayısıyla $\mathrm{H}_{3}$ hipotezi kabul edilmektedir.

Tablo 7. Denetçinin Mesleki Deneyiminin Çevresel Faktörleri Yordamasına İlişkin Regresyon Analizi

\begin{tabular}{|l|l|l|l|l|l|l|l|l|l|l|}
\hline Bağımsız Değişken & Bağımlı Değişken & $\mathbf{B}$ & $\begin{array}{l}\text { Std. } \\
\text { Hata }\end{array}$ & $\mathbf{( \beta )}$ & $\mathbf{t}$ & $\mathbf{P}$ & $\mathbf{R}$ & $\mathbf{R}^{\mathbf{2}}$ & $\mathbf{F}$ & $\mathbf{P}$ \\
\hline Mesleki Deneyim & Çevresel Faktörler & 18,887 &, 084 &, 060 & 91,007 &, 00 & 0,60 &, 004 &, 642 &, 424 \\
\hline
\end{tabular}

Anlamlılık düzeyi (significance) p>.05 olduğu için kurulan regresyon modeli anlamsızdır. İlişsinin yordanmasına yönelik yapılan regresyon analiz sonuçlarına göre denetçilerin mesleki deneyimlerinin çevresel faktörler üzerinde etkisi olmadığı görülmektedir. Dolayısıyla $\mathrm{H}_{4}$ hipotezi reddedilmektedir.

\section{SONUÇ}

Küreselleşme ve yaşanan hızlı değişimlerin bir sonucu olarak işletme faaliyetleri daha karmaşık hale gelmiştir. Bu gelişmeler denetim sürecini de etkilemiş, denetim faaliyetlerinin yürütülmesi zorlaşmıştır. Denetim faaliyetlerinin kalitesinin artırılması için denetim firmalarının değişimlere uyum sağlaması, yeni gelişmeleri yakın takip etmesi ve uyum sağlaması önemlidir.

Çalışmanın amacı denetçinin mesleki deneyiminin denetim kalitesi üzerinde etkisinin olup olmadığını ortaya koymaktır. Bu amaçla bağımsız denetçilerden veriler anket yöntemiyle elde edilmiştir. Keşfedici faktör analizi sonucu kalite ölçeğindeki 4 faktör toplam varyansın \%61,956'sını açıklamaktadır. Denetçinin mesleki deneyimi ile denetim kalitesi arasındaki ilişkiyi ortaya koymak için dört tane hipotez oluşturulmuştur. $\mathrm{H}_{1}$ : Denetçinin mesleki deneyimi ile girdi faktörleri arasında anlamlı bir ilişki vardır. Bu hipotez reddedilmiştir. Denetçilerin mesleki deneyimlerinin girdi faktörleri üzerinde etkisi olmadığı görülmüştür. $\mathrm{H}_{2}$ : Denetçinin mesleki deneyimi ile süreç faktörleri arasında anlamlı bir ilişki vardır. Bu hipotez reddedilmiştir. Denetçilerin mesleki deneyimlerinin süreç faktörleri üzerinde etkisi olmadığı görülmüştür. $\mathrm{H}_{3}$ : Denetçinin mesleki deneyimi ile çıktı faktörleri arasında anlamlı bir ilişki vardır. Bu hipotez kabul edilmiştir. Denetçilerin mesleki deneyimlerinin çıtı faktörleri üzerinde pozitif yönde ve zayıf düzeyde anlamlı bir etkisinin olduğu görülmüştür. $\mathrm{H}_{4}$ : Denetçinin mesleki deneyimi ile çevresel faktörler arasında anlamlı bir ilişki vardır. $\mathrm{Bu}$ hipotez reddedilmiştir. Denetçilerin mesleki deneyimlerinin çevresel faktörler üzerinde etkisi olmadığı görülmüş̧ür. $\mathrm{Bu}$ çalışmada, denetçinin mesleki deneyiminin, denetim süresinin nihai çıktısı olan denetim raporlarının kalitesi üzerinde etkisinin olmadığ 1 , az deneyimli bir denetçi ile daha deneyimli bir denetçinin aynı kalitede denetim raporu hazırladığı sonucuna ulaşılmıştır. 


\section{KAYNAKÇA}

Al- Qatamin K.I. ve Salleh Z. (2020). Audit quality: a literature overview and research synthesis. IOSR Journal of Business and Management (IOSR-JBM), 22(2), 56-66.

DeAngelo, L. E. (1981), Auditor size and audit quality. Journal Of Accounting And Economics, 3 (3), 183-199.

FRC (2008). Financial Reporting Council the Audit Quality Framework, https://www.frc.org.uk/getattachment/46582304-32b1-43bb-b614-90318b295f28/The-Audit-QualityFramework-Feb-2008.pdf

Hair, J. F., Black, W. C., Babin, B. J., Anderson, R. E., ve Tatham, R. L. (2006). Multivariate data analysis. New Jersey: Pearson University Press.

IAASB (2014). A Framework For Audit Quality: Key Elements That Create An Environment For Audit Quality, https://www.ifac.org/system/files/publications/files/A-Framework-for-Audit-Quality-Key-Elements-that-Createan-Environment-for-Audit-Quality-2.pdf

Mushiirah, A.B., Keshav, S. ve Neeveditah P.M. (2018). An investigation of audit quality in mauritius. Theoretical Economics Letters, 8(13), 2773-2787.

Noverini, C., Hutahacan T.F., Gustylia A., Veronica A. ve Gunawan E. (2020). Effect of independence, professionalism and experience on audit quality. Journal of Business, Management, and Accounting, 2(2), 272-280.

Palmrose, Z. (1988). An analysis of auditor litigation and audit service quality. The Accounting Review, 63(1), 55-73.

Prasanti, D.H., Ramadhanti W. ve Puspasari (2019). Effect of independence, work experience and competence on audit quality with professional ethics as moderating variable. Jurnal Akuntansi Aktual, 6(1), February, 223-233.

PCAOB (2011). Concept Release on Auditor Independence and Audit Firm Rotation;, Notice of round1ahle, PCAOB Release No. 2011-006, August 16, 2011, https://pcaobus.org/Rulemaking/Docket037/Release_2011-006.pdf

Sattar, U., Javeed S.A. ve Latief R. (2020). "How audit quality a ects the firm performance with the moderating role of the product market competition: empirical evidence from pakistani manufacturing firms. Sustainability, 12, 4153, 1-20.

Sulaiman, N.A. (2011). Audit quality in practice: a study of perceptions of auditors, audit committee members and quality inspectors. Yayınlanmamış Doktora Tezi. Manchester Business School, Faculty of Humanities.

Vaicekauskas, D. ve Mackevicius J. (2014). Developing a framework for audit quality management in audit firms. Zeszyty Teoretyczne Rachunkowossci, 75 (131), 171-193.

Zahmatkesh S. (2017). The effect of auditor features on audit quality. Tekhne Review of Applied Management Studies, $15,79-87$.

https://www.kgk.gov.tr/Portalv2Uploads/files/Duyurular/v1/Teblig/BA\%C4\%9EIMSIZ\%20DENET\%C4\%B0M\%20Y ETK\%C4\%B0LEND\%C4\%B0RME\%20TEBL\%C4\%B0\%C4\%9E\%C4\%B0.pdf (Erişim Tarihi, 01.02.2021)

https://biac.org/wp-content/uploads/2020/01/the-importance-of-audit-quality-for-trust-in-business1.pdf?fbclid=IwAR1dopJq2r_YE7SFYVYJvNUWc-SY4jiZfJIX7G2VTnuk1094YPSXu3mlwx8 (Erişim Tarihi, 05.01.2021)

https://asic.gov.au/regulatory-resources/financial-reporting-and-audit/auditors/improving-and maintainingauditquality/?fbclid=IwAR2K9Fj8vdVBXW7mYR17NX8Kos4_kJy6koXQHPnuue9j3TYeDs8E8y3 KPew (Erişim Tarihi, 06.01.2021) 